\title{
ASPEK POSITIF FUNGSI POLITIK AGAMA
}

\author{
Lia Eliawati \\ Sekolah Tinggi Ilmu Sosial Dan Ilmu Politik Muhammadiyah Sinjai \\ Email:lia01@gmail.com
}

\begin{abstract}
Abstrak
Artikel ini menjelaskan beberapa fungsi politik agama yang telah digunakan oleh berbagai institusi, kelompok, dan politisi. Agama sebagai salah satu struktur sistem sosial memiliki beberapa fungsi sosial termasuk politik, baik positif maupun negatif. Dengan mempelajari karyakarya sebelumnya tentang agama dan bukti baru penulis, di sini dari sudut pandang politik, eufungsi (fungsi positif) ini akan digali. Penulis yakin bahwa, tidak seperti para sosiolog, para ilmuwan politik belum mempertimbangkan fungsi agama dalam arena politik. Nah, artikel ini mencoba memperjelas beberapa fungsi tersebut untuk menjawab pertanyaan-pertanyaan berikut: apa saja fungsi politik positif agama khususnya di era baru? Apakah agama telah bergeser ke fungsi baru? Berkenaan dengan pertanyaan-pertanyaan tersebut, dari pendekatan fungsionalisme, dan setelah mendefinisikan agama, penulis mencoba menjelaskan beberapa fungsi tersebut seperti pengaruh integritas dan kohesi, Pengaruh dalam kebijakan domestik dan kebijakan publik, perilaku memilih, nasionalisme, hubungan internasional dan sebagainya.

Kata kunci: Agama, Fungsi Politik Agama, Partisipasi Politik, Mobilisasi, Ideologi, Tatanan Politik, Nasionalisme Agama, Politik Agama
\end{abstract}

\begin{abstract}
This article describes some of the political functions of religion that have been used by various institutions, groups and politicians. Religion as a social system structure has several social functions including politics, both positive and negative. By studying previous works on religion and the author's new evidence, here from a political point of view, this eupuncture (positive function) will be explored. The author believes that, unlike sociologists, political scientists have not considered the function of religion in the political arena. So, this article tries to clarify some of these functions in order to answer the following questions: what are the functions of the positive politics of religion, especially in the new era? Has religion shifted to a new function? With regard to these questions, from the functionalism approach, and after defining religion, the author tries to explain some of these functions such as the influence of integrity and cohesion, influence on domestic policy and public policy, voting behavior, nationalism, international relations and so on. Keywords: Religion, Political Function of Religion, Political Participation, Mobilization, Ideology, Political Order, Religious Nationalism, Political Religion
\end{abstract}

JURNAL PAPATUNG: Vol. 2 No. 1 Tahun 2019

ISSN: 2715-0186 


\section{A. PENGANTAR}

Sebagian besar penyelidikan empiris, dalam beberapa tahun terakhir, menunjukkan bahwa keyakinan dan praktik agama sama lazimnya seperti di masa lalu, jika tidak lebih. Sebagian besar orang di negara sekuler mengidentifikasi diri mereka sebagai pengikut suatu agama. Pada tahun 2001, Gill dalam sebuah artikel menyebutkan bahwa menurut beberapa survei nilai kata, tiga perempat dari responden di 43 negara terus menganut kepercayaan pada beberapa dewa supernatural, $63 \%$ menganggap diri mereka religius, dan 70\% mengaku memiliki denominasi agama. (insang, 2001). Jadi, agama masih menjadi faktor penting dalam politik.

Di dalam politik, memang efek agama bisa dideteksi dari segala segi. Di tingkat budaya politik, keyakinan agama memberikan kontribusi; Di tataran konstitusi, isu agama dan negara masih menjadi perdebatan. Misalnya, di beberapa negara berkembang, agama menjadi dasar konstitusi, dan di Inggris sebagai negara maju, raja secara teknis masih menjadi kepala negara dan Gubernur Tertinggi Gereja Inggris yang Mapan (Moyser, 1991: 13). Dan di dalam arena politik kelompok penekan, politik elektoral, dan pembuatan kebijakan, agama mengambil bagian yang substansial. Di A.S., para uskup Katolik Roma menegaskan pandangan mereka tentang senjata nuklir dan hak-hak bayi yang belum lahir; kelompok-kelompok Yahudi yang kuat melobi atas nama Israel; efek dari kaum injili yang dilahirkan kembali pada politik (Ibid: 23). Terlepas dari survei dan investigasi yang dilakukan, peristiwa dunia selama beberapa tahun terakhir di beberapa negara seperti Mesir, Siprus, dan Suriah menunjukkan bahwa agama sedang dan akan terus menjadi pemain utama dalam politik. Jadi, agama merupakan elemen yang konsisten dalam masyarakat manusia yang dapat dianggap sebagai bagian dari masyarakat secara keseluruhan dengan beberapa fungsi. Dan, sebagaimana investigasi sejarah menunjukkan bahwa politik dan agama telah berinteraksi hingga saat ini. JURNAL PAPATUNG: Vol. 2 No. 1 Tahun 2019 ISSN: 2715-0186 
Memang pengaruh terpenting dari kekuatan sosial agama adalah muncul dalam bentuk kemampuan politiknya (Mofidi, 2005). Meskipun demikian, setelah pemisahan berbagai disiplin ilmu dalam ilmu sosial, agama dan fungsi sosialnya telah diteliti oleh beberapa sosiolog, terutama para fungsionalis, termasuk beberapa penyebutan beberapa fungsi politik sebagai bagian darinya tetapi tidak secara jelas. dan dengan judul ini sementara upaya dalam ilmu politik tidak signifikan dan sebagian besar studi telah dibatasi pada agama politik dan fundamentalisme. Berkaitan dengan hal tersebut, dan sebagai kelanjutan dari tulisan sebelumnya tentang agama dalam politik, artikel ini membahas aspek positif dari fungsi politik agama dari sudut pandang ilmu politik1. Untuk tujuan ini, pertama-tama kita harus mendefinisikan agama dan memisahkan definisi substantif dan fungsionalnya.

\section{B. PEMBAHASAN}

\section{Agama: Definisi Substantif dan Fungsional}

Ada banyak definisi untuk agama. Semua definisi menekankan aspek-aspek tertentu dari agama dan mengecualikan yang lain. Di sini, kami menyebutkan definisi Smith yang seharusnya kurang lebih komprehensif. Dalam kata-katanya, 'Agama adalah rangkaian keyakinan spiritual yang mempersatukan pemeluknya sebagai satu komunitas'. Dengan demikian, agama merupakan salah satu struktur dalam sistem sosial. Selain aspek moral, dapat dibahas sebagai eksistensi materialistik dalam yayasan agama (seperti bentuk kelembagaan seperti 'gereja' dalam agama Kristen, Masjid dalam Islam dan kuil dalam agama-agama Timur), kelompok agama dan gerakan keagamaan (Hamilton, 2001 ). Karenanya, menurut Malcolm Hamilton (2001), agama memiliki deskripsi substansial dan fungsional di mana di sini kami mempertimbangkan definisi 
fungsional. Maksudnya di sini adalah untuk mengekspos fungsi dan peran agama dalam politik.

\section{Fungsionalisme Struktural dan Agama}

Secara umum pendekatan fungsional tidak memiliki nilai-nilai dan sebaliknya lebih menitikberatkan pada peran objektif agama. Dalam pandangan Merton, agama sebagai bagian dari masyarakat dapat memiliki fungsi positif atau negatif dan fungsi laten atau manifest. Dalam teks ini, sebagaimana yang akan dijelaskan, kita berkaitan dengan eufungsi (fungsi positif) dalam kaitannya dengan agama dalam politik dan ilmu politik. Namun sebelum itu, berikut tentang apa yang dikatakan di atas, kita meninjau agama dan fungsinya dalam politik.

\section{Fungsi Politik Agama}

Pemerintah, secara umum, menyukai kompleks keagamaan yang dapat "digunakan" untuk tujuan politik selama sejarah (Holt et al, Op.cit: 206). Sehubungan dengan penggunaan agama oleh pemerintah dan politisi, kita dapat merujuk pada apa yang dilakukan Bonapart dan politisi lain dalam pemerintahannya di Prancis. Bagi mereka, 'Gereja ada di negara bagian', sedangkan 'negara bukan di gereja' (Bhargava, Op.cit: 102). Ini menunjukkan pentingnya agama bagi negara dan memang menunjukkan kebenaran di awal era sekularisme. Mereka tidak mengatakan gereja terpisah dari negara karena mereka sebagai politisi ingin menggunakan agama. Hingga saat ini, metode ini terus dilanjutkan sehingga sebagian kita melihat pemisahan agama dari negara tetapi tidak dari politik bahkan di negara-negara sekuler.

Hubungan antara agama dan emosi penting dalam politik. Hubungan antara agama dan emosi adalah hubungan yang panjang dan intim. Agama selalu menjadi sumber pengalaman emosional yang mendalam (Emmons dan Paloutzian, 2003). Dalam politik, emosi religius dan pengaruh agama terhadap emosi digunakan dalam berbagai JURNAL PAPATUNG: Vol. 2 No. 1 Tahun 2019 ISSN: 2715-0186 
cara seperti dasar-dasar partai, revolusi dan pembentukan negara baru, pemungutan suara dan pemilu, segmentasi, perang, politisasi, pemilu, isu nasional, otoritas karismatik. Isu-isu ini dapat dibagi menjadi negatif dan positif seperti yang dilakukan Wach (1971) seperti itu. Ia menyebutkan bahwa pengaruh agama ada dua: ada pengaruh positif atau keterpaduan kohesif, dan ada pengaruh negatif, merusak, dan menghancurkan '(Wach, 1971: 35). Jadi, sebagaimana telah disebutkan, dalam kaitannya dengan fungsi referensi sosial, ada dua jenis fungsi; eufungsi (fungsi positif) atau disfungsi (fungsi negatif). Atas dasar kategori ini, di sini kami secara relatif memandang aspek positif dari fungsi politik agama.

\section{Aspek Positif dari Fungsi Politik Agama}

Ada beberapa kategori dalam kaitannya dengan fungsi positif agama yang disebutkan oleh penulis lain. Berkenaan dengan prasyarat fungsional kehidupan kelompok, Johnstone mengatakan bahwa agama memiliki lima fungsi: perekrutan / reproduksi, sosialisasi, menghasilkan tingkat barang dan jasa yang memuaskan, memelihara ketertiban, memelihara rasa tujuan (Johnstone, 1975: 101-105). Dan juga O "Dea mendaftar enam fungsi positif agama bagi individu dan masyarakat: Memberikan dukungan dan penghiburan, memberikan keamanan emosional dan identitas, mempromosikan tujuan kelompok, kritik terhadap sosial yang ada dan membentuk dasar untuk protes sosial, memberikan perasaan individu identitas penting dalam proses pematangan dan krisis kehidupan individu (Hamilton, Op.cit: 138). Selain fungsi-fungsi yang disebutkan di atas, dan fungsi pengintegrasian seperti fungsi sosial utama agama, ada fungsi lain yang dikutip beberapa penulis seperti solidaritas dan tatanan sosial, simbolisasi. Di sini kami menyoroti beberapa di antaranya dan juga fungsi politik lainnya.

JURNAL PAPATUNG: Vol. 2 No. 1 Tahun 2019

ISSN: 2715-0186 


\section{Partisipasi politik}

Partisipasi politik memiliki berbagai dimensi termasuk non-partisipasi yang diinformasikan untuk mengambil tanggung jawab penting dalam pemerintahan. Berkenaan dengan agama, di sini kami hanya melihat empat dimensinya. Menurut Smith, dalam keadaan tertentu agama memiliki kontribusi positif dalam proses politisasi dan mempromosikan politisasi massa dengan menyediakan simbol-simbol sakral. Identitas agama dan konflik komunitas agama merupakan faktor penting bagi kolektivitas politik dan politisasi, terutama di dunia ketiga dan masyarakat transisi (Karaman, 2004). Fakta bahwa berbagai agama terus menarik pemeluknya setelah beberapa milenium menyebutkan kekuatan mobilisasi mereka. Semua agama lama telah melayani mobilisasi politik dalam beberapa dekade terakhir sehingga gerakan keagamaan telah menunjukkan kemampuan luar biasa untuk memobilisasi aksi kolektif termasuk protes politik (insang, Op.cit: 118). Di berbagai negara, fungsionaris agama sebagai kelompok kepentingan ulama (kelompok asosiasi) memiliki pengaruh dalam arena politik dalam proses politisasi massa. Di sisi lain, ada politisi awam terkemuka yang secara efektif memanfaatkan simbol-simbol agama dalam beberapa tradisi keagamaan. Komunitas agama sebagai kelompok kepentingan agama non-asosiasional mulai dipolitisasi terutama dalam situasi konflik dimana isu sebenarnya adalah sosial, politik dan ekonomi (Karaman, Op.cit).

\section{Partai-partai politik}

Seperti yang dikatakan Jean Blondel dalam bukunya "Comparative Government", partai struktural adalah semacam partai yang salah satunya adalah partai agama. Agama sebagai struktur masyarakat menjadi faktor pembentuk partai. Donald Smith membedakan tiga jenis partai politik-agama Dunia Ketiga. Pertama, partai komunal seperti Hindu Mahasabha atau Jana Sangh di India yang sebagian besar muncul sebagai JURNAL PAPATUNG: Vol. 2 No. 1 Tahun 2019 ISSN: 2715-0186 
respons terhadap konflik aktual atau laten dalam masyarakat yang pluralis secara agama. Mereka bertindak untuk melindungi kepentingan komunal. Jenis kedua dari partai politik agama adalah partai berbasis sekte seperti Umat di Sudan utara. Jenis ketiga adalah partai ideologis agama yang berfungsi dalam masyarakat di mana agama minoritas secara politik tidak penting seperti banyak partai Amerika Latin misalnya Demokrat Kristen di Chili dan Masyumi di Indonesia. Partai-partai ini tidak berorientasi pada konflik dengan kelompok agama lain, tetapi ingin berbicara dengan asumsi ideologis yang melandasi dan membentuk masyarakat (Johnstone, Op.cit: 203-204).

Karenanya, di satu sisi, agama berperan membentuk partai politik dan agama berperan sebagai sumber ideologis partai tersebut. Ada beberapa partai agama di negaranegara Barat yang berpengaruh pada kehidupan politik di negara-negara ini seperti partai demokrasi Kristen dan Partai Katolik Roma di Prancis dan... (lihat; Bhargava, Op.cit: 119). Di sisi lain, pengaruh agama dan umat beragama dalam partai atau politisi menggunakan agama untuk memperkuat partainya. Johnstone dalam menjelaskan pengaruh agama terhadap afiliasi partai politik, seperti yang telah disebutkan, mengatakan: „pandangan populer yang dianut bahwa anggota dari kelompok agama yang berbeda cenderung lebih memilih satu atau partai politik besar" (Johnstone, Op.cit: 76)

\section{Grup Penekan}

Kelompok penekan telah menjadi bagian yang kaya dari kisah agama dalam politik. Kelompok agama dapat menjadi kelompok penekan institusional yang mempromosikan pandangan khusus mereka tentang masalah dalam agenda dan kebijakan publik saat ini. Politisi menggunakan kelompok-kelompok ini untuk melaksanakan program mereka atau melawan oposisi mereka. Mereka mungkin muncul dalam bentuk melobi legislatif yang membuat kontak dengan administrasi eksekutif atau JURNAL PAPATUNG: Vol. 2 No. 1 Tahun 2019 ISSN: 2715-0186 
bahkan pergi ke pengadilan. Ini mungkin juga memerlukan pembangunan dan penggunaan hubungan dengan partai politik dan membentuk aliansi dengan kelompok penekan yang berpikiran sama. Tindakan mereka dapat mencakup mobilisasi pemeluk agama, pembentukan gerakan politik yang diilhami agama, dan upaya untuk menyadarkan opini publik melalui media massa. Bahkan, di dunia modern, para pemimpin agama mungkin secara aktif mencari jabatan sendiri. Meskipun sebagian besar kelompok agama tidak berusaha masuk ke ranah politik, dan melihatnya sebagai arena koruptor dan korup (Moyser, op.cit, p: 7).

\section{Pemilu dan Perilaku Memilih}

Agama merupakan salah satu faktor yang berpotensi mempengaruhi pola pemungutan suara dan pilihan yang diambil pada hari pemilu. Baik afiliasi agama dan indeks religiusitas telah berulang kali menunjukkan korelasi yang cukup kuat dengan pola pemungutan suara tertentu (Johnstone, Op.cit: 195). Dalam masyarakat tradisional dan di kalangan petani, agama memiliki pengaruh yang besar setiap kali tokoh agama mereka merekomendasikan untuk memilih, kebanyakan dari mereka berpartisipasi dan memberikan suara kepada calon yang mereka inginkan. Agama juga memiliki pengaruh ini di sebagian besar masyarakat modern, misalnya di kalangan pemilih Amerika. Pidato politik kepada umat beragama menjadi sama pentingnya dan strategis seperti tempat tradisional lainnya. Banyak kandidat politik, juga, saat ini menyadari bahwa mengkomunikasikan agama kepada massa dapat membantu kesuksesan dan menarik dukungan dalam jajak pendapat (Martin, 2010). Memang, bagian penting dari kekuasaan berasal dari massa rakyat bahwa agama memiliki pengaruh di antara mereka. Sebuah studi klasik tentang sistem partai barat mengungkapkan bahwa agama mempertahankan arti penting yang luar biasa dalam memperbaiki keberpihakan pada suara. Dengan kata lain, kelompok agama dapat membentuk komunitas politik, membentuk dan JURNAL PAPATUNG: Vol. 2 No. 1 Tahun 2019 ISSN: 2715-0186 
memobilisasi kegiatan pemilihan anggotanya saat mereka bereaksi terhadap kandidat, partai, dan masalah dalam kampanye (moyser, Op.cit: 7)

Penggunaan perbedaan di antara agama dan menarik berbagai kelompok oleh partai politik untuk memberikan suara dan menggunakan suara mereka sangat umum di banyak negara seperti A.S. (lihat: Eversole, 2010 \& Martin, Op.cit). Secara tradisional, di negara ini kecenderungan Katolik Amerika untuk memilih Partai Demokrat dan Protestan lebih cenderung mendukung Partai Republik. Beberapa survei nasional yang dilakukan dalam berbagai periode menunjukkan kecenderungan ini (untuk beberapa contoh lihat: Johnstone, Op.cit: 197).

Eversole menyebutkan, kebangkitan hak beragama sejak 1980-an telah menciptakan kesan bahwa afiliasi agama telah menjadi kekuatan yang signifikan dalam politik sebagai preferensi etnis, gender, dan ras. Sehingga kehadiran gereja secara teratur dapat menunjukkan kecenderungan untuk memilih Republikan sebagai lawan dari Demokrat, meskipun banyak tergantung pada masalah pada waktu dan pemilihan tertentu (Eversole, Op.cit). Dalam sebagian besar pemilihan presiden AS, berbagai kelompok agama mendukung salah satu partai dan kandidatnya. Misalnya evangelis Konservatif memainkan peran penting dalam pemilihan presiden Ronald Reagan (Gill, Op.cit). Pada tahun 2000, fundamentalis dan sebagian besar kelompok agama lainnya mendukung W. Bush (Eversole, Op.cit). Oleh karena itu, sebagai Martin telah menyebutkan bahwa para politisi Amerika telah mengakui perlunya iman yang saleh untuk memenangkan jabatan politik yang tinggi (Martin, Op.cit).

\section{Simbolisasi dan Ideologi}

Aspek yang saling terkait antara agama, ideologi, dan simbolisme, memiliki fungsi dalam politik. Beberapa definisi agama menyebutkan konotasi simbolik seperti definisi Geertz dan Mardin (lihat: Karaman, Op.cit). Dalam hal ini, dan sehubungan JURNAL PAPATUNG: Vol. 2 No. 1 Tahun 2019 ISSN: 2715-0186 
dengan komunalisasi politik, kami melihat mobilisasi berdasarkan simbol-simbol agama (Bhargava, Op.cit: 23). Karena esensi emosi religius dipandang tidak dapat diungkapkan, semua upaya untuk mengungkapkannya bersifat simbolis. Sepanjang sejarah, simbol telah dan masih menjadi salah satu stimulan paling kuat dari sentimen manusia. Berbagi simbol umum adalah cara yang sangat efektif untuk memperkuat persatuan sekelompok penyembah. Dengan demikian, makna fungsional lain dari agama adalah simbolisme. Ini membantu menciptakan sistem nilai sosial yang terintegrasi dan koheren dengan simbolisasi (Nottingham, Op.cit: 18-19). Sesuai dengan apa yang dikemukakan di atas maka agama berada dalam ranah ideologi dan simbolisme. Nandy menyebut dua jenis agama; agama-sebagai-keyakinan dan agama-sebagai-ideologi. Dalam kata-katanya, Modernisasi pertama-tama menghasilkan agama-sebagai-ideologi dan kemudian menghasilkan sekularisme untuk memenuhi tantangannya terhadap 'ideologi ketatanegaraan modern' (Bhargava, Op.cit: 22-23). Ada juga beberapa definisi lain tentang agama dalam kaitannya dengan ideologi sebagai definisi Fromm dan Madan (lihat: Karaman, Op.cit \& Madan, 2011:3). Jadi, agama berfungsi sebagai ideologi seperti dalam kaitannya dengan partai politik, atau oleh individu karismatik. Dengan demikian, agama sebagai ideologi, misalnya, pada tataran budaya mengamankan kemungkinan lingkungan konseptual bagi laki-laki. Dalam konteks ini, seperti ideologi, itu menjadi sistem simbol (Madan, Op.cit: 3). Agama, terutama dalam masyarakat transisi, merupakan satu-satunya sumber konten ideologis (Karaman, Op.cit). Dalam kaitan ini, terlepas dari pentingnya peran agama sebagai ideologi bagi partai politik di banyak negara seperti Iran dan Pakistan yang sudah disebutkan, kita bisa menyebut agama sebagai ideologi hingga oposisi politik. Menurut Smith (1971), ada "potensi politik yang berkelanjutan dari simbol-simbol agama." Dan seperti yang dikatakan Tibi (1983), "kekuatan mobilisasi simbol-simbol agama berfungsi sebagai formula ideologis untuk JURNAL PAPATUNG: Vol. 2 No. 1 Tahun 2019 ISSN: 2715-0186 
oposisi politik." Agama dapat memperkuat oposisi politik oleh institusi politik untuk mengasimilasi mereka. Oleh karena itu, gerakan politik-agama berfungsi sebagai kekuatan mobilisasi yang menggunakan agama sebagai ideologi penggerak yang memberikan pertentangan politik dengan simbol-simbol agama dan dengan mengaitkan tujuan-tujuan keagamaannya. Di sini, aspek simbolik dan fungsi integratif Islam untuk mobilisasi politik menjadi penting, terutama di sebagian besar gerakan anti-imperialis di paruh pertama abad ke-20 (Karaman, Op.cit). Dalam pandangan Maxime Rodinson Islam adalah ideologi yang memfasilitasi mobilisasi sosial dan politik melalui aspek simbolik dan kekuatan kohesif yang kuat bagi komunitas mukmin terutama makna simbolik Allah, terlepas dari semua perbedaan sosial di antara mereka. Jadi, keyakinan dan kesamaan pengalaman keagamaan penting untuk mempersatukan umat Islam (Karaman, Op.cit). Seperti di Iran selama revolusi 1979 beberapa ideolog seperti Syariati dan Motahari mengubah agama tradisional menjadi agama ideologis dan menggunakan syi'ah untuk mobilisasi massa. Oleh karena itu, Singkatnya, seperti yang dikatakan Hamilton 'agama mungkin cocok untuk penggunaan ideologis'. Dan sebagai manipulasi ideologis dapat digunakan untuk tujuan ideologis (Hamilton. Op.cit; 95).

\section{Integrasi, Solidaritas, dan Order politik}

Berkenaan dengan pengaruhnya terhadap struktur sosial, agama dianggap sebagai faktor integratif khususnya dalam pandangan Durkheim (Johnstone, Op.cit: 142). Dalam sistem politik-agama tradisional, seperti yang ditunjukkan oleh Smith (1970), agama mengintegrasikan "masyarakat dengan menyediakannya kerangka makna dan pengalaman yang sama. Melalui proses sosialisasi biasa, kaum muda memperoleh seperangkat kepercayaan dan nilai yang terkait dengan simbol-simbol yang sakral "(karaman, Op.cit). Johnstone mempertimbangkan beberapa cara di mana agama dipandang memberikan pengaruh yang menyatu dalam masyarakat (Johnstone, Op.cit: JURNAL PAPATUNG: Vol. 2 No. 1 Tahun 2019 ISSN: 2715-0186 
143): 1- Penguatan normatif; 2-Integrasi ke dalam hubungan kelompok yang bermakna; 3-katalis untuk menegaskan kembali nilai-nilai sosial; 4- bantuan dalam menyesuaikan diri dengan krisis pribadi; 5- stimulus untuk ekspresi estetika; 6-Sumber kesejahteraan sosial. Dalam pandangan Nottingham, tidak ada masyarakat yang dapat mempertahankan dirinya sendiri tanpa konsensus minimum di antara anggotanya bahwa agama merupakan bantuan penting dalam hal ini dengan bertindak sebagai agen untuk integrasi nilai dan kontrol sosial (Nottingham, Op.cit: 60). Fungsi ini menjadikan harmoni kohesif untuk solidaritas sosial.

Pengalaman religius yang umum dan motif perlindungan diri atau dakwah bertindak sebagai kekuatan kohesif yang kuat, dan menciptakan perasaan solidaritas yang menyatukan para anggota (Wach, Op.cit: 35). Dalam kaitan ini, bila ada faktor yang terintegrasi, politisi bisa memanfaatkannya untuk solidaritas politik. Solidaritas adalah alat terbaik untuk kemenangan dalam politik. Kekuatan politik tersebut dapat dimenangkan yang memiliki solidaritas politik yang baik di antara kekuatannya. Sebagaimana telah disebutkan, agama merupakan salah satu faktor yang dapat mempengaruhi integrasi manusia melalui itu. Jadi, agama bisa berpengaruh pada solidaritas dan tatanan politik. Misalnya, Agama dalam masyarakat transisi menentukan definisi kekuasaan dan otoritas yang dapat diterima melalui mekanisme legitimasi politik dan integrasi sosial dan memberikan keanggotaannya rasa memiliki dan koherensi. Karenanya, stabilitas politik tetap terjaga. Dalam masyarakat ini, keberlangsungan fungsional agama baik sebagai institusi dan sistem kepercayaan membantu agama untuk bertindak sebagai penyangga. Ini merekonstruksi ikatan baru solidaritas dan identitas melalui simbol, artefak atau organisasi solidaritas tradisional untuk mengatasi keterasingan (karaman, Op.cit). Integrasi dan solidaritas memiliki peran penting dalam tatanan politik. Tatanan politik adalah pusat politik yang harus JURNAL PAPATUNG: Vol. 2 No. 1 Tahun 2019 ISSN: 2715-0186 
diperhatikan oleh pemerintah dan politisi. Dan juga, berpikir tentang politik, di satu sisi, adalah berpikir secara teratur. Untuk tujuan ini, menurut Durkheim, agama memberikan gambaran tentang prinsip yang mengatur tubuh kolektif kita. Klaim-klaim politik kolektif adalah imanen dalam ketuhanan, kekuatan supra-manusia, dan praktek-praktek yang berhubungan dengannya (Friedland, 2001). Jadi, agama telah membuktikan dirinya sebagai kekuatan pemersatu yang paling efektif dan kuat dalam kehidupan semua jenis negara. Karena tatanan sosial dan politiknya tidak sewenang-wenang tetapi didasarkan pada prinsip-prinsip agama yang statis, negara terikat untuk memenuhi persyaratan agama (Wach, Op.cit: 289-290). Sehubungan dengan hal ini kita harus menyebutkan pentingnya menjaga ketertiban dalam kelompok agama. Salah satu tugas utama yang harus dilakukan grup adalah menjaga ketertiban (Johnstone, Op.cit: 105). Ada berbagai jenis kelompok ini yang urutannya digunakan dalam politik. Di satu sisi, dengan menjaga ketertiban di setiap kelompok dan bantuan ulama dan organisasi mereka, tatanan politik yang lebih besar juga dapat dibuat. Di sisi lain, seringkali efektif bila sebagian besar penduduk menjadi anggota komunitas religius. Dan mayoritas yang lebih besar lebih efektif. Agama, misalnya dalam dunia modern, merupakan salah satu unsur solidaritas dalam 'proyek integrasi Eropa'. Sejarawan Eropa telah memfokuskan pada agama sebagai dasar identitas Eropa sehingga Uni Eropa disebut sebagai 'Klub Kristen' (Fokas, Op.cit).

\section{Sentralisasi kekuatan}

Fungsi integrasi sosial agama dapat dilayani oleh pemerintahan yang kuat dan terpusat (Abraham, 2003: 83). Sepanjang sejarah peradaban, banyak penakluk dan pemimpin telah berusaha menyatukan populasi dengan mendeklarasikan satu agama resmi. Dalam hubungan ini, kita bisa menyebut Islam sebagai contoh yang baik. Pada awalnya, tidak ada institusi politik dan ekonomi sentral dalam masyarakat Arab tetapi JURNAL PAPATUNG: Vol. 2 No. 1 Tahun 2019 ISSN: 2715-0186 
oleh Islam mereka diikat menjadi satu. Dengan mendeklarasikan Islam, klan Arab dan pada akhirnya banyak kelompok nasional yang berbeda meskipun perpecahan bersatu (Richerson \& Newson, 2009). Islam memiliki kekuatan pemersatu yang besar dan fungsi integratif yang kuat. Berkat aspek ini, komunitas penganut Islam, umma, secara konseptual bersatu, terlepas dari semua perbedaan dengan penerimaan umum akan satu Tuhan (karaman, Op.cit). Islam sebagai agama politik, juga, bukan hanya tentang hubungan individu dengan Tuhan, tetapi tentang komunitas orang-orang beriman yang terorganisir secara politik, umma, yang disebut dengan kedaulatan mereka (Ibid). Di bawah khalifah kedua, Omar, gerakan itu dikonsolidasikan dan kombinasi karakteristik Islam antara otoritas sekuler dan agama dijamin (Nottingham, Op.cit: 153). Praktik ini telah berlangsung sepanjang sejarah negara-negara Islam, bahkan setelah era Khilafah misalnya di Iran setelah revolusi Iran 1979 di mana pihak pemenang (misalnya Syiah puritan) menggunakan agama untuk melakukan sentralisasi yang kuat di negara ini. Meskipun bangsa lain namun Persia belum puas dan telah melawan sentralisasi ini dan mereka melihat fungsi ini sebagai penyalahgunaan agama oleh pemerintah pusat.

Jika kita menganggap otoritas sebagai kekuatan yang sah, menurut Weber, agama memiliki peran dalam melegitimasi tiga jenis otoritas. Sebagai bagian dari tradisi, sumber karisma religius sebagai sejenis karisma, dan sumber konstitusi di beberapa negara, agama berperan dalam otoritas tradisional, karismatik, dan legal-rasional. Dalam hubungan ini, di sebagian besar masyarakat, agama memiliki peran penting. Kebanyakan negara, termasuk negara sekuler, menggunakan agama untuk mendapatkan legitimasi massa. Hubungan antara agama dan negara ini memiliki asal yang panjang. Ruang Kerajaan menggunakan agama Kristen, dan Kekhalifahan Islam juga menggunakan Islam. Bahkan saat ini, banyak negara Islam dengan politisi sekuler menggunakan Islam untuk mendapatkan legitimasi. Dalam kebanyakan masyarakat JURNAL PAPATUNG: Vol. 2 No. 1 Tahun 2019 ISSN: 2715-0186 
religius dalam konstitusi, agama resmi disebutkan. Dan, seperti yang telah kami kutip, di beberapa negara termasuk negara sekuler, agama merupakan salah satu sumber konstitusi seperti Irak, Iran, Malaysia dan Pakistan. Terlepas dari peran agama dalam legitimasi tradisional dan hukum yang disebutkan di atas, agama memiliki peran penting dalam otoritas karismatik. Menurut Weber, kepribadian karismatik adalah salah satu dari tiga tipe otoritas "murni" untuk gerakan keagamaan dan sosial lainnya (Holt et al, Op.cit: 118). Ada beberapa tipe karisma dan karismatik, tetapi menurut Wach tipe religius itu fundamental (Wach, Op.cit: 337). Jenis ini terkait dengan otoritas berbasis agama yang menggambarkan berbagai macam karunia ketuhanan (rasa religius) yang dianugerahkan kepada umat beriman sehingga sejumlah tanda karismatik ditafsirkan sebagai indikasi nikmat supernatural (Turner, 1996: 146). Sebagai salah satu pemimpin yang lebih karismatik kita dapat menyebutkan kepada Ayatollah Khomeini selama revolusi Iran (1979) dan setelah itu sampai kematiannya (1988). Namanya juga "Roh allah". Sebagian besar umat beragama menganggapnya sebagai 'roh Tuhan' dan sebagai pemimpin super Iran memiliki kekuatan penuh, otoritas absolut dan pengaruh tinggi di antara orang awam. Agama memiliki peran penting dalam nasionalisme dan konstruksi bernegara. Itu adalah bagian dari identitas komunal, budaya bersama dan kesinambungan sejarah sehingga, dengan 'bangsa' menjadi terjerat erat. Agama dapat menjadi sarana di mana suatu bangsa atau sekelompok orang mengekspresikan identitas dan aspirasinya (Moyser, Op.cit: 4). Kontrol politik dan sosial melalui agama difasilitasi tidak hanya melalui identifikasi agama dengan tujuan nasional, tetapi juga melalui identifikasi kepala negara dengan bentuk ketuhanan (Holt et al, Op.cit: 210). Di sisi lain, sehubungan dengan perkembangan militer dan politik, sebuah agama atau kultus dapat dibentuk yang membantu mengintegrasikan negara atau kerajaan yang bersatu. 
Misalnya Israel, Roma, Meksiko, Peru, Cina, Jepang, Mesir, Babilonia, kerajaan Het, dan Persia (Wach, Op.cit: 300).

Dalam kebanyakan komunitas Semitik kuno, pria dan dewa mereka dianggap sebagai unit sosial, politik, dan agama. Secara historis, di Asiria, "Tuhan", "kota", dan "bangsa" semuanya memiliki nama yang sama. Dan juga selama tahap Yudaisme yang paling awal diketahui, Yahweh memiliki karakter eksklusif dan nasional sehingga tidak ada catatan mesianik yang signifikan yang muncul di antara orang-orang Yahudi sampai mereka mengembangkan kesadaran nasional yang kuat. Beberapa bagian Alkitab menyatakan bahwa Mesias adalah yang diurapi Tuhan terutama untuk tujuan politik. Demikian pula, seperti yang telah ditunjukkan Wash, "Ide tentang kebangsaan dan ketuhanan terjalin dalam konsep romawi dari genius populi romani... "(Holt et al, Op.cit: 208). Dalam hubungan ini, ada contoh kontemporer lainnya. Di Jepang, Shinto mengidentifikasi suatu bangsa dengan ketuhanannya. Nasionalisme di Jepang secara fungsional telah menjadi 'agama negara dengan kepala negara melayani sebagai Tuhan yang paling berkuasa'. Dan kata dalam bahasa Jepang untuk "pemerintah" berarti "urusan ibadah". Memang, agama dan nasionalisme Jepang modern telah menjadi satu. Dan juga bagi orang Arab, fanatisme agama adalah jaminan terbaik bagi perasaan nasional dan semangat patriotik, dan itu adalah senjata terkuat perlawanan terhadap agresi asing yang menggambarkan salah satu fungsi dari identifikasi lembaga negara dan agama (Holt et al, Op.cit: 209-210). Tentang hubungan antara agama dan identitas nasional, kasus Yunani juga menjadi contoh yang baik. Di negara ini, Gereja Ortodoks di bawah sistem millet Ottoman berusaha untuk memobilisasi sebagian besar masyarakat Yunani pada isu-isu yang berkaitan dengan identitas nasional Yunani (Fokas, Op.cit). Hal lain tentang agama dan nasionalisme terkait dengan nasionalisme agama. Keddie, dalam menjelaskan dua jenis yang disebutnya sebagai "politik agama baru", ingin JURNAL PAPATUNG: Vol. 2 No. 1 Tahun 2019 ISSN: 2715-0186 
membedakan penggunaan otoritas pemerintah secara religius dari kontrol agama atas wilayah; Dengan kata lain "fundamentalisme" dari "nasionalisme agama". Menurutnya, 'Gerakan Religionasionalis' biasanya tidak menekankan kitab suci atau praktik keagamaan tertentu, sedangkan fundamentalis melakukannya. Jadi, itu hanya menjadikan agama sebagai basis identitas kolektif bangsa dan sumber nilai dan tujuan akhirnya. Ini hanya merupakan pilihan yang layak jika kolektivitas memiliki dasar agama yang sama. Dengan demikian, nasionalisme agama dimungkinkan di India, Israel, Iran, Turki, Pakistan dan Amerika Serikat, sebagian karena keberadaan agama hegemonik seperti Hindu, Yudaisme, Islam Syiah, Islam Sunni, dan Protestan, masingmasing (Friedland, Op.cit). Praktik teritorial agama Zionis Gush Emunim di Israel dan BJP nasionalis Hindu dan RSS di India keduanya dipahami dan dibenarkan dalam hal narasi agama. Keduanya mempolitisasi penggunaan ruang ritual dan praktik ritual keagamaan sebagai perangkat mobilisasi (ibid).

Memang di satu sisi, kaum nasionalis religius menjadikan politik sebagai kewajiban agama. Mereka semua membaca teks agama secara politis. Nasionalisme ini menawarkan ontologi kekuasaan tertentu yang terungkap dan ditegaskan melalui praktik-praktik politiknya dan objek sentral perhatian politiknya, praktik-praktik yang menempatkan solidaritas kolektif dalam keyakinan beragama. Agama, dengan demikian, mengambil bagian dari tatanan simbolis negara bangsa dan bahwa nasionalisme kontemporer dicampurkan dengan agama. Nasionalisme semacam ini mengisi bentuk negara yang ada dengan muatan budaya baru dan sumber otoritas baru. Terkadang itu adalah bentuk agama yang dipolitisasi di mana agama menjadi dasar penilaian dan identitas politik (ibid). Di sisi lain, nasionalisme religius memperluas logika institusional agama ke dalam domain negara-bangsa, memperoleh otoritas dari perintah ilahi yang absolut, bukan agregasi subyektif dari demo. Hal ini tidak asing JURNAL PAPATUNG: Vol. 2 No. 1 Tahun 2019 ISSN: 2715-0186 
dengan pembentukan negara-bangsa modern. Bahkan pembentukan banyak identitas nasional modern non-Barat dan gerakan nasionalis diliputi oleh narasi dan mitos agama, simbolisme dan ritual seperti Iran, Sri Lanka, India, Pakistan, Arab Saudi, Israel, dan Palestina untuk mengambil beberapa contoh saja. Bahkan para Islamis militan yang memiliki cita-cita universal, hampir semuanya berusaha menciptakan tatanan Islam di dalam negara-bangsa (Ibid) yang ada. Di Isreal, mereka menggunakan agama dan hak ketuhanan mereka seperti yang mereka katakan untuk menciptakan negara ini (Davis, 1994: 112). Oleh karena itu, kaum nasionalis religius selalu memusatkan energinya pada negara-bangsa tempat mereka tinggal.

Seperti yang sudah saya sebutkan, Keddie menyebutkan dua jenis politik agama; fundamentalisme dan nasionalisme agama, tetapi politik agama tidak terbatas pada dua jenis ini. Itu bisa dilihat di banyak bidang. Tujuan dari politik agama, disini adalah pemahaman pemerintah dan politisi tentang fungsi agama dan pentingnya menjalankan dan mempromosikan program-programnya di tingkat nasional. Jadi, berbeda dengan politik agama yang dihadapi kaum fundamentalis mereka, seperti yang dijelaskan. Misalnya, banyak politik agama terlihat di A.S. Sehubungan dengan nasionalisasi dan penggunaan agama dalam politik nasional oleh politisi, negara ini adalah contoh yang baik. Agama dan politik di negara ini terkait erat satu sama lain, sebuah tandem yang terwujud dalam beberapa cara utama. Dari upaya kelompok kepentingan khusus agama untuk mempengaruhi kebijakan publik hingga tujuan kandidat untuk menarik sebagian besar penduduk, keyakinan agama adalah tujuan yang diinginkan serta alat yang digunakan oleh para politisi yang bersemangat.

Negara ini adalah salah satu negara sekuler yang penting tetapi seperti yang dikatakan Brian Jackson (2011), agama telah menjadi senjata politik di negara itu. Secara historis, agama telah terlihat jelas dalam politik nasional AS. Dalam kaitan ini, Justin D. JURNAL PAPATUNG: Vol. 2 No. 1 Tahun 2019 ISSN: 2715-0186 
Martin menyebutkan beberapa kasus. Presiden John Adams mengatakan bahwa "konstitusi kami dibuat hanya untuk orang-orang yang beragama dan bermoral. Ini sama sekali tidak memadai untuk pemerintah mana pun. " Setiap presiden Amerika secara terbuka mengidentifikasi dirinya sebagai Protestan atau Katolik Roma. Jimmy Carter memproklamirkan dirinya sebagai Kristen evangelis dan George W. Bush memproklamasikan 'Yesus Kristus' sebagai pahlawan dalam hidupnya. Dan politisi lain yang bersaing untuk jabatan tinggi tampaknya memperhatikan hubungan antara iman dan kemenangan dalam pemungutan suara (Martin, Op.cit). Ada beberapa contoh bahwa para kandidat di pemilu Amerika memiliki politik ini untuk menarik rakyat. Hal itu terlihat dalam pidato mereka untuk berbagai kelompok (lihat beberapa contoh dalam: Jackson, 2011). Dalam kaitannya dengan politik agama kita juga dapat menyebutkan 'Strategi Tuhan' di USA. Menurut David Domke dan Kevin Coe, ada empat sinyal yang menjadi inti dari strategi ini: "[a] cting sebagai pendeta politik, dengan berbicara dalam bahasa setia"; "Menggabungkan Tuhan dan negara, dengan menghubungkan Amerika dengan kehendak ilahi"; "Menawarkan tindakan persekutuan, dengan merangkul elemen religius ikonik"; dan "terlibat dalam politik moralitas, dengan menyuarakan isuisu penting". Dalam strategi ini dijelaskan bahwa 'Bagaimana Agama Menjadi Senjata Politik di Amerika' dan bagaimana Partai Republik "menggunakan religiusitas yang diperhitungkan untuk mentransformasikan politik Amerika". Ini dimulai sejak masa Ronald Reagan ketika Jerry Falwell menggunakan kaum evangelis untuk membantunya dalam pemilihan. Saat G.W. Bush terpilih, strategi Tuhan menjadi penggabungan kehendak Tuhan dan kebijakan negara. Dalam hubungan ini, politisi menggunakan Tuhan untuk memajukan agenda, untuk terhubung dengan para pemilih, dan membuat beberapa orang sangat tidak nyaman (Jackson, Op.cit). 
Terlepas dari apa yang telah disebutkan di atas, seringkali para politisi dan pemerintah memperhatikan struktur sosial untuk legislasi, pembuatan kebijakan dan implementasi kebijakan. Mereka harus mempertimbangkan agama masyarakat dan tindakan mereka terkait dengan kebijakan tersebut, terutama di tingkat lokal. Misalnya, dalam kaitan ini, nasib RUU sel punca, pada musim panas 2006, menunjukkan peran penting agama dalam politik Amerika. Meskipun mendapat dukungan luas dari kongres (kedua majelis), RUU tersebut tidak pernah berhasil melewati meja semak karena sebagian besar kelompok agama konservatif yang mampu meyakinkan presiden sifat tercela RUU tersebut (Martin, Op.cit). Jadi, agama dapat berfungsi untuk mempromosikan penolakan yang sangat aktif terhadap kebijakan pemerintah seperti kasus gerakan perdamaian, atau aborsi (Moyser, Op.cit: 8). Oleh karena itu, dalam pembuatan dan implementasi kebijakan agama sangat diperhatikan.

\section{Penggunaan revolusioner}

Perilaku politik massa tidak terbatas pada pemungutan suara. Aktivitas lain yang sangat penting adalah protes dan bahkan 'kekerasan politik'. Agama dapat menjadi sarana untuk memusatkan perhatian dan mengintensifkan keterasingan dari seluruh rezim politik yang dapat menyebabkan kekerasan politik, pemberontakan dan revolusi (Ibid). Dalam situasi ini, membenarkan adanya kekerasan meskipun terkadang dalam mood yang paling buruk mengarah pada tragedi kemanusiaan dan cenderung pada aspek negatif seperti apa yang terjadi setelah revolusi Iran (1979) bahwa sebagian besar pejabat rezim sebelumnya dan juga penentang rezim baru dieksekusi.

Jadi, agama memiliki pengaruh penting dalam revolusi. Seperti yang dikatakan Weber „konsep revolusi agama paling konsisten dengan rasionalisme asketik duniadalam yang berorientasi pada perintah suci perintah Tuhan. di dalam dunia. Dalam agama Kristen, hal ini benar dalam Calvinisme yang menetapkan kewajiban agama JURNAL PAPATUNG: Vol. 2 No. 1 Tahun 2019 ISSN: 2715-0186 
untuk mempertahankan iman melawan tirani dengan menggunakan kekerasan... '(Weber di: http://www.ne.jp). Namun terlepas dari revolusi agama yang bagi mereka berubah menjadi ideologi, ia juga berpengaruh pada revolusi lain. Revolusi ekonomi dan politik yang mengantar ke dunia modern bertepatan di tahap awal dengan revolusi agama yang dikenal sebagai pemberontakan protestan (Nottingham, Op.cit: 154). 'Etika Protestan dan semangat kapitalisme' yang merupakan karya Weber secara khusus menunjukkan bagaimana variasi Calvinis dari Protestan dan kapitalisme yang sedang berkembang memperkuat satu sama lain. Ini menunjukkan keterkaitan antara perkembangan pemikiran agama dan perubahan bersamaan dalam lembaga ekonomi dan politik (Ibid: 157). Berkenaan dengan revolusi politik, kita bisa menyebut Revolusi Amerika. Menurut Frieland, revolusi ini dipersiapkan oleh transformasi yang tersebar dalam kepercayaan Prootestan yang dikenal sebagai "Kebangkitan Besar" yang menempatkan basis otoritas keagamaan dalam iman pribadi, bukan dalam pentahbisan, pengakuan doktrin, atau hierarki gereja (Friedland, Op. .cit). Ada contoh lain dalam dunia Kristen. Misi Kristen dan Kristen telah membantu menghasilkan di dunia ketiga baik revolusi melawan kolonialisme dan dorongan revolusioner menuju modernisasi (Nottingham, Op.cit: 191). Dan, juga, kita dapat menyebutkan peran Katolik dalam Revolusi Sandinista Nacaraguan pada 1979, dan kebangkitan gerakan Solidaritas di Polandia dan peran Gereja Katolik pada akhirnya jatuhnya komunisme di sana (Gill, Op.cit \& Fokas, Op. cit). Di antara agama, secara keseluruhan, revolusi adalah tradisi khusus yang selalu ada dalam isi Islam. Dalam ranah politik, Islam memiliki peran dan fungsi yang beragam mulai dari legitimasi dan advokasi status quo hingga perangkat untuk mengumumkan protes dan melancarkan revolusi (Mofidi, Op.cit). Dalam hal ini, kita dapat menyebut negara-negara Islam sebagai Aljazair di mana gerakan reformis merupakan komponen penting dari perjuangan pembebasan melawan Prancis, dan Iran JURNAL PAPATUNG: Vol. 2 No. 1 Tahun 2019 ISSN: 2715-0186 
di mana para ulama berpartisipasi aktif dalam Revolusi Konstitusi. Pada abad ke-20 melawan modernitas di Iran, fenomena khas dari "tradisionalisme revolusioner," yaitu, "gerakan umum untuk membela Islam melawan pengaruh Barat," muncul (Moaddel, 2002). Dan juga, dalam revolusi Iran tahun 1979, ulama Islam menggulingkan rezim Iran dengan dukungan rakyat yang meluas. Oleh karena itu, meskipun agama dapat menjadi alat untuk mempertahankan status quo, ia juga dapat menjadi salah satu faktor katalisator perubahan dan salah satu ujung tombak revolusi. Jadi agama dan revolusi terjalin secara aneh dan rumit di dunia non-barat (Nottingham, Op.cit: 183).

Dalam politik, salah satu masalah terpenting bagi politisi adalah pemeliharaan kekuasaan. Untuk tujuan ini mereka harus mempertimbangkan faktor-faktor sosial dan apa pun yang penting bagi massa yang memasukkan agama dan simbol-simbol agama. Agama dan pemuka agama memiliki pengaruh di antara massa, karena para politisi ini menggunakan agama untuk menjaga pemerintahan dan kekuasaannya sehingga berusaha memuaskan para pemuka agama dengan cara dekat dengan mereka. Dalam hal ini, menurut Hood di berbagai rezim otoriter seperti Iran, Arab Saudi, dan Mesir para pemimpin mengandalkan berbagai tafsir Islam untuk mempertahankan kekuasaan. Kebanyakan ulama percaya bahwa para pemimpin negara Islam menggunakan Islam sebagai alat untuk mempertahankan kekuasaan politik eksklusif. Dan mereka menunjukkan kontradiksi antara doktrin agama Islam dan praktik politik dan praktis (Hood, 2004: 6-8). Di sebagian besar negara ini, meskipun mereka sering tidak menyerukan pemerintahan Islam tetapi politisi sekuler karena menjaga konten partai dan kelompok Islam, masyarakat dan gerakan Islam, dan sebagai akibatnya mempertahankan kekuasaan mereka dalam konstitusi Hukum Islam telah didasarkan seperti yang telah kami sebutkan. . Dan juga, terkadang mereka menerima tanggung jawab formal agama seperti raja Arab Saudi yang memiliki tanggung jawab 'Kaeba'. JURNAL PAPATUNG: Vol. 2 No. 1 Tahun 2019 ISSN: 2715-0186 
Agama memiliki fungsi penting dalam hubungan antar negara dan hubungan internasional. Agama mempersiapkan bidang bersama untuk hubungan yang lebih baik di antara beberapa negara. Misalnya hubungan antar negara Islam dan membuat beberapa organisasi internasional seperti 'Organisasi Konferensi Islam' (OKI). Dan, seperti yang kami sebutkan sebelumnya, itu berpengaruh pada proyek integrasi di UE. Di wilayah yang sangat luas, bisa dibayangkan beberapa relasi antara Muslim dan Kristen bahkan Yahudi sebagai pemeluk agama Ibrahim. Kita bisa melihat banyak dari hubungan ini berdasarkan agama di berbagai tempat di dunia. Jadi, agama memiliki fungsi penghubung antara berbagai bangsa dan negara, dan berperan sebagai faktor yang baik untuk menyamakan bidang bagi hubungan internasional.

\section{KESIMPULAN}

Sebagaimana disebutkan, agama memiliki deskripsi yang substansial dan fungsional. Agama adalah rangkaian kepercayaan, dan salah satu struktur sosial dalam masyarakat dengan banyak fungsi sosial. Dalam artikel ini, kami telah memusatkan perhatian pada sebagian dari fungsi-fungsi ini di bawah fungsi politik agama. Agama, secara relatif, memiliki dua fungsi; fungsi positif dan negatif dalam politik (misalnya telah bertindak sebagai faktor penyatuan dan perpecahan). Dan, secara historis terjadi fluktuasi antara dua peran ini. Meskipun tidak ada batasan yang jelas antara keduanya, dan dalam sudut pandang yang berbeda, terkadang fungsi positif dipandang sebagai penyalahgunaan agama dalam politik. Meskipun demikian, meskipun dari sudut pandang sekularisme dan pandangan ideal penggunaan agama dan politik agama dalam politik tidak dianjurkan namun realitas masyarakat khususnya di dunia ketiga mendorong para politisi dan pemerintah untuk memperhatikan fungsinya. Dan fungsifungsi ini, seperti yang kami sebutkan, tidak sama hari ini seperti dulu. Menurut JURNAL PAPATUNG: Vol. 2 No. 1 Tahun 2019 ISSN: 2715-0186 
masyarakat beberapa perubahan terlihat. Ada beberapa fungsi positif baru seperti efek pada mobilisasi, pemungutan suara dan kebijakan publik, pembuatan dan pelaksanaan kebijakan (walaupun bisa juga negatif berkaitan dengan kondisi dan kebijakan), nasionalisme agama, hubungan internasional dan sebagainya. Karenanya, dalam ilmu politik, fungsi politik agama dalam masyarakat harus lebih diperhatikan daripada masa lalu.

\section{DAFTAR PUSTAKA}

Abrahan. M. Francis (2003), Teori Sosiologi Modern, Pengantar, New Delhi: pers universitas oxford.

Bhargava. Rajeev (2010), Sekularisme dan pengkritiknya, New Delhi: pers universitas oxford, kesan kesembilan.

Davis. Charles (1994), Religion and the making of society, Essays in social theology, Cambridge University Press.

Emmons. Robert. A. dan Raymond F. Paloutzian (2003), psikologi agama, Annu. Rev. Psychol, 54: 377-402. Diunduh dari www.annualreviews.org

Eversole. Theodore W. (2010), "Agama dan Perilaku Memilih." Ensiklopedia Kampanye AS, Pemilu, dan Perilaku Pemilu. SAGE Publications. Di: <http://www.sageereference.com/campaigns/Article_n365.html>.

Fokas. Effie (2009), "Religion: Towards a Postecular Europe?", SAGE Handbook of European Studies, SAGE Publications. 10 Mei. 2010 di: http://www.sageereference.com/hdbk_eurostudies/Article_n23.html.

Friedland. Roger (2001), 'Nasionalisme agama dan masalah representasi kolektif', Annu. Pdt. Sociol, 27: 125-152. Diunduh dari www.annualreviews.org

Gill. Anthony (2001), 'Agama dan Perbandingan Politik', Annu. Rev. Polit. Sci. 2001. 4: $117-38$.

Holt. Rinehart dan Winston (1958), sosiologi agama, A.S., universitas negeri Wayne.

Kap. Steven J. (2004), Perkembangan Politik dan Teori Demokrasi, New Delhi, Perentice-hall of india.

Jackson. Brian (2011), 'The God Strategy: How Religion Being a Political Weapon in America', David Domke dan Kevin Coe, Retetoric Review, 30: 3,320-323.

Johnstone. Ronald L. (1975), Religion and Society in Interaction, the sociology of religion, New Jersey: Prentice, INC.

Karaman. M. Lutfullah (2004), „religion, politics, and mobilization: a theoretical perspective with a special not 
on "The Indian Khilafat Movement "ee, Alternatives: Turkish Journal of International Relations, Vol.3, No.1, Spring.

Madan. T.N. (2011), Secularism and Fundamentalism in India, Modern Myths, Locked minds, second edition, sixth impression, New Delhi: Oxford university press.

Moaddel. Mansoor (2002), ,The study of Islamic culture and politics: An Overview and Assessmente ${ }^{\text {ee }}$ Annu. Rev. Sociol, 28:359-386. Downloaded from www.annualreviews.org

Martin. Justin D. (2010), „Religion in politicse, SAGE Publications, at: http://www.sageereference.com/hdbk_eurostudies/Article.html.

Malcolm. Hamilton (2001), The sociology of religion, New York: Routledge.

Mofidi. Sabah (2005), "political function of religion in Kurdistan (whit focus on the Quran school movement)", rojav, (in persian), Tehran: Tehran university, No 1. 